Journal of Agriculture, Food and Environment (JAFE)

Journal Homepage: http://journal.safebd.org/index.php/jafe

http://doi.org/10.47440/JAFE.2020.1302

Original Article

\title{
A Time Series Analysis for Supply Response Scenario of Food Grains in Bangladesh: The Quest of Structural Changes
}

\author{
M. A. Islam* , M. S. Rahaman, M. A. R. Sarkar and M. C. Rahman \\ Agricultural Economics Division, Bangladesh Rice Research Institute, Gazipur-1701, Bangladesh.
}

\section{Article History}

Received: 29 June 2020

Revised: 25 July 2020

Accepted: 26 July 2020

Published online: 06 September 2020

\section{*Corresponding Author}

Mohammad Ariful Islam, Agricultural Economics Division, Bangladesh Rice Research Institute, Gazipur-1701, Bangladesh. Email: arifagecon@gmail.com

\section{Keywords}

Growth rate; Structural break; Supply response function; Time series analysis; Autocorrelation

\begin{abstract}
A B S T R A C T
Using time-series data, we examined the structural stability and supply response scenario of cereal food production for the last five decades. Analyzes revealed that growth in the area for Aus, Aman, and Boro rice slowed in the period 1971/72-1983/84, but surprisingly the production growth accelerated due to amazing technological advancements and the implementation of government subsidies on complementary inputs. Applying the Nerlovian supply response model, the result showed that, lagged area for Aus, Boro, and wheat was positive and significant, implying that the preceding year area under Aus, Boro, and wheat had a significant influence on land allocation for the following year. The lagged relative yield of Boro and Aus turned out positive implying that in Boro season farmers took into consideration the lagged relative yield of Boro vis-a-vis wheat in the allocation of land for Boro rice and wheat cultivation. The negative price risk variable further implied farmers' risk aversion response towards price fluctuation. The yield risk variable was found negative for Boro and wheat, implying that this factor did not influence the cultivation of these two crops. Meanwhile, although Bangladesh achieved marginally food security, government and policymakers should focus on stabilizing the market price at harvest time to realize sustainable food security in the future, and researchers should prioritize breaking the yield ceiling as well as developing different stresstolerant varieties. In the same way, steps should be taken through public and private partnerships to disseminate different crop varieties so that productivity could be enhanced at the desired level.
\end{abstract}

\section{Introduction}

In Bangladesh, the area under modern rice varieties started increasing only from 1967, when the Bangladesh Rural Development Academy (BRDA) in Cumilla started pushing cultivation of IR8 with the tube well irrigation through farmers' cooperatives (Bose, 1974). The area under mechanized irrigation was less than $3 \%$ of the cultivated land, and chemical fertilizers were being just introduced with heavy subsidies by the government. By 1970, only $2 \%$ of the land was covered by modern rice varieties and the use of chemical fertilizers at farmers' level was at a low scale (Hossain, 2003). During the 1970s the technological progress in the rice sector was limited in spite of heavy government investment in the agriculture sector (Hossain, 1984). The growth in food grain production originated rather from the expansion of area under high yielding varieties of rice and wheat. In this perspective, social scientists pointed out two major constraints to technological progress in Bangladesh agriculture as: (i) prevalence of unequal land distribution, and (ii) the dominance of sharecropping and tenancy arrangements (Abdullah, 1976; Januzi and Peach, 1980; Boyce, 1987).

Rice and wheat are considered as the major food grains of Bangladeshi people. Rice is considered to be the synonym of food (Brolley, 2015), and as such rice production is vital to the Bangladesh economy. Rice alone constitutes about $84 \%$ of the total cereal food grain produced annually in the country (FPMU, 2020). An early estimate indicates that, by the year 2030, a total food grain of 43.65 million tons will be required for a projected population of 185 million (Kumar et al., 2012; UN, 2019). Under the present scenario, more than three-fourths of the country's cropped area is devoted to rice cultivation, on which $60 \%$ of the agriculture labor force is directly or indirectly engaged (BBS, 2019). Furthermore, rice alone contributes about four percent of the total gross domestic product (GDP) in the country (BBS, 2019). Among all crops, rice is the driving force of Bangladesh's agriculture. 
This indicates that production growth was only driven by intensification. Indeed, the share of high yielding variety (HYV) rice on total rice increased to $85 \%$ in $2018 / 19$ from about $82 \%$ in $2010 / 11$ with a steady increase since $2007 / 08$ (BBS, 2016; BBS, 2019). However, it is well argued that the shifting of croplands from rice to non-rice crops has been taking place on a considerable scale in the recent past (Alam et al., 2011).

Available evidence shows that the growth in acreage and production of maize in Bangladesh has much accelerated rate compared to that for rice over the period 1987/88 towards 1999-2000 and also in the subsequent periods. In Rabi season, the area under maize increased by $46 \%$ and $21 \%$ in drought-prone and favorable areas, respectively (Alam et al., 2011). The continuous declining trend in the wheat area and reversely increasing trend for both area and production of maize in recent years has become an important concern of the planners and policymakers. There was a structural break during the early to mid-the 1980s (after independence) by heavy state intervention in agriculture, including subsidization of inputs (Hasan, 2012). During the period of 1984-85, we experienced structural adjustment reforms initiated by the Word Bank (period with more liberalized trade regime) (WB, 1994).

Bangladesh made notable progress in achieving food security despite an extreme pressure of population on limited land resources and an agrarian structure dominated by small and tenant farmers. It is presumed that Bangladesh would probably face enormous challenges over the next decade in achieving food self-sufficiency and ensuring food security for all individuals and groups in the country. However, the national level food-grain (rice and wheat) security situation (in terms of physical access to food) in Bangladesh can be viewed in Fig. 1. It appears that the overall food-grain production has increased during the last four decades. Food security status was more or less the same up to 2000/01. After that, the status increased up to $2010 / 11$ and then started decreasing till 2016/17 and once again showed increasing. For achieving sustainable food security, the government took various measures to increase food grain supply. According to national household survey 2016, food grain consumption decreased sharply and food security status also increased steadily in Bangladesh (HIES, 2019). Data in Fig. 1 further depict that, food grain consumption has decreased in between 2017/18 and $2018 / 19$ compared to $2016 / 17$ due to lower food grain consumption per capita at the individual as well as household level.

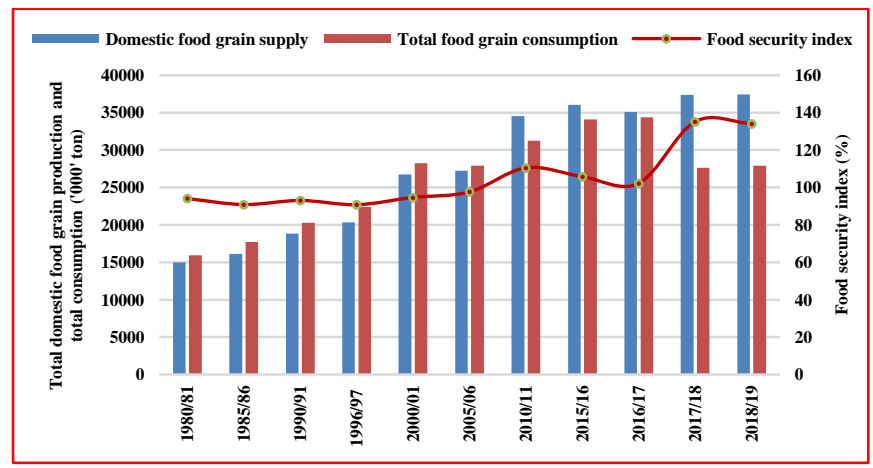

Fig 1. National level food security status over the years in Bangladesh. Prepared by authors based on data from BBS 2019 and FPMU 2020.
It is worth mentioning that, analysis of supply response would provide useful information on the extent of farmers' response to price and other pertinent economic factors. The studies on the supply response of agricultural crops are enormous in world literature. Few attempts have also been made in the crop sector of Bangladesh. Very early initiative had been made by Rahman (1986) to show the supply response of rice and rabi crops, using the well-established $\mathrm{Ner}$ love (Nerlove, 1956) model. Begum et al. (2002) has used the partial adjustment model to the Bangladesh wheat sector; where Kamal (2007) employed the co-integration and error correction model to show the supply response of Boro rice. The supply response behavior of pulse crops in a broader spectrum in Bangladesh has been estimated by Miah et al. (2009). Yaseen et al. (2011) has done an extensive study to analyze the supply response of rice, wheat, cotton, maize, sugarcane, and rapeseed in Bangladesh by using CobbDouglas production function. All of these previous studies used the time series data to show the supply response behavior of different crops in Bangladesh. However, our study investigated the supply response of the food grains in different political and/or development situation, and policy options of the country using econometric models. As such, the present study attempts to analyze the growth behavior and factors influencing the supply of various cereal crops over the pre and post-independence period in Bangladesh, as well as analyze the impact of structural changes on area and productivity of different cereals. Such a study would hopefully be immensely useful in meeting the need for changing strategies and policies in view of the recent developments in the country. The specific objectives of the present study have been formulated as: 1) to analyze the level of structural change/stability in acreage and productivity of cereal crops over several decades; and 2) to know the acreage response of various factors determining decision regarding allocation of land among different cereal crops.

\section{Methodology \\ The data}

The present study used mainly secondary data. Time series data on area, production, and yields of different food grains for 70 years from 1947/48 to 2018/19 were obtained from the report of Kurosaki (2011) and different issues of the statistical yearbook of Bangladesh. The whole period (1947/48 to 2018/19) was divided into two viz pre-independence period/period I (1947/48 - 1970/71: period of non-adoption of improved cereal crop varieties), and post-independence period/ period II (1971/72 - 2018/19: adoption period of improved cereal varieties). Post independent period was also divided into two sub-periods i.e., no liberalized trade regime/sub-period I (1971/72 - 1983/84) and more liberalized trade regime/sub-period II (1984/85 - 2018/19) to compare the rate of changes occurred in the area, production and yield of different cereals and to explore the causes of changes.

\section{Measuring the trend of change}

In order to measure the trend of change, we only considered post independent period due to data gap. Five-year average was used to estimate fluctuation rate and a pertinent index was used to compare the changes in the area, production, and yield of different cereal crops considering 1971-1975, 198185 , and 1991-95 as the base period for rice, wheat, and maize, respectively. Noticeably the base period is considered according to the data availability. The pertinent index was formulated using the following formula: 


$$
\text { Index }=\left\{\frac{\text { Current year value }}{\text { Base year value }} \times 100\right\}
$$

\section{Growth rate estimation}

The growth rates of area, production, and yield of cereal crops were worked out by fitting a semi-log function (exponential growth function) of the following type:

$$
\begin{aligned}
& y=e^{\alpha+\beta t} \\
& \text { or lny }=\alpha+\beta t
\end{aligned}
$$

Where, $\ln$ = Natural logarithm;

$\mathrm{y}=$ Area in thousand hectare (ha) or production in thousand metric ton or yield ( $\mathrm{t} / \mathrm{ha}$ );

$\beta=$ Regression coefficient, i.e., growth rate (in ratio scale);

$\mathrm{t}=$ Time period (year);

$\alpha=$ Intercept; and,

$\mathrm{e}=$ disturbance term .

\section{Test of structural stability}

It was assumed that the effect of policy reform might have influenced food grain production during the period 1971/72 2018/19 since a substantial technological advancement in this sector took place and those were disseminated during this period. Taking into consideration this, a structural stability test was performed to verify the magnitude of structural changes. Production and productivity of different cereal crops between two periods of $1947 / 48-1970 / 71$ to $1971 / 72$ - 2018/19, and $1971 / 72$ - 1983/84 to $1984 / 85$ - 2018/19 were examined. The following regression model was used for structural stability test (Miah et al. (2009):

$$
\operatorname{LnY} Y_{i}=\beta_{1}+\beta_{2} D_{1}+\beta_{3} X_{i}+\beta_{4}\left(D_{1} * X_{i}\right)+U_{i}
$$

Where, $Y_{i}=$ Area (thousand ha) or production (thousand metric ton) or yield ( $\mathrm{t} / \mathrm{ha}$ ) of different food grains in $\mathrm{i}^{\text {th }}$ year; $\mathrm{D}_{1}=$ Period dummy ( 1 for $2^{\text {nd }}$ period, otherwise $0) ; X_{i}=$ Time $(i=1,2,3, \ldots \ldots . n) ; \beta_{1}$ is general intercept; $\beta_{2}$ is differential intercept; and $\beta_{4}$ is differential slope coefficient (also called slope drifter). $\beta_{2}$ indicates how much the slope coefficient of $2^{\text {nd }}$ period differs from the slope coefficient of $1^{\text {st }}$ period implying that there was a structural change occurred in $2^{\text {nd }}$ period over time. When, $D_{1}=1$, then $\operatorname{InY}_{\mathrm{i}}=$ $\left(\beta_{1+} \beta_{2}\right)+\left(\beta_{3+} \beta_{4}\right) X_{i}=\gamma_{1}+\gamma_{2} X_{i}$; When $D_{1}=0$, then InY $Y_{i}=$ $\beta_{1+} \beta_{2} X_{i}$. The null hypothesis of the structural stability test is Ho; $\gamma_{1}=\beta_{1}$ and $\gamma_{2}=\beta_{3}$. If the $1^{\text {st }}$ null hypothesis is accepted then it indicates that no change occurred in the $2^{\text {nd }}$ period, which is originated from the intercept (due to autonomous production). If the $2^{\text {nd }}$ null hypothesis is accepted then it indicates that no structural change occurred in the $2^{\text {nd }}$ period, which is originated from the slope coefficient (due to adoption effect).

\section{Estimation of supply response}

Nerlovian partial adjustment lag model (Nerlove, 1956) was used for estimating supply response for different cereal corps (e.g., Boro, Aus, and wheat). It is noted that, the Aman rice is not considered in the analysis for the unavailability of price and other related data. The model implies that the change in the current area is in proportion to the difference between the long-run equilibrium area and an actual area in the previous year. The double-log form of the Nerlovian partial model was employed because of its suitability of fitness to the data. Hence, the following basic equation could be employed:

$$
\begin{aligned}
\operatorname{LnA}_{t}=b_{0}+b_{1} L \operatorname{LRP}_{t-1}+b_{2} \operatorname{LnRY}_{t-1}+b_{3} \operatorname{LnCV}_{R P} \\
+b_{4} \operatorname{LnCV}_{R Y}+b_{5} \operatorname{LnA}_{t-1}+I_{t}+U_{t}
\end{aligned}
$$

Where, ' $t$ ' refers to the $t^{\text {th }}$ production period;

$\mathrm{A}_{\mathrm{t}}=$ The actual area (ha) planted under the respective crop and used as the dependent variable;

$\mathrm{RP}_{\mathrm{t}-1}=$ Lagged relative price, i.e., ratio of the price of the crop concerned to the price of the competitive crop;

$\mathrm{RY}_{\mathrm{t}-1}=$ Lagged relative yield, i.e., the ratio of yield of the crop concerned to yield of the competitive crop;

$\mathrm{CV}_{\mathrm{RP}}$ and $\mathrm{CV}_{\mathrm{RY}}=$ The coefficients of variation of the preceding one years' relative price and relative yield, respectively;

$\mathrm{A}_{\mathrm{t}-1}=$ Lagged area (ha) planted under the crop;

$\mathrm{I}_{\mathrm{t}}=$ Gross irrigated area (ha) under all selected crops; and,

$$
\mathrm{U}_{\mathrm{t}}=\text { Error term. }
$$

\section{Results and Discussion}

Trend in area, production, and yield of cereal food grains As explained in the earlier section, an index approach considering five years average was applied to show the trend in area, production and yield of different food grains and the pertinent data are presented in Table 1 . The area indices constructed for different food grains showed an overall increasing trend for Boro rice, total rice, and maize area concerning their corresponding base period. On the other hand, the area indices under wheat increased up to 2001 - 2005 from its base index period and then decreased up to 2016 - 2019. Aus rice area indices had a decreasing trend which continued up to 2006 - 2010 from its base index period and then reached a plateau up to 2018 - 2019. The rice area indices under Aman had an increasing trend up to 1981-1985 from its base period, but afterward, it decreased up to 2006 - 2010. Once again Aman area indices increased a bit up to 2016 - 2019. The reason behind this could be that the decrease in Aus and wheat area happened since there was a remarkable area shifting to Boro rice and maize cultivation in Bangladesh over this period (Alam et al., 2011).

Data in Table 1 further show that production of food grains like Aman, Boro, total rice, and maize increased up to 2016 2019 from their respective base period probably because of government took heavy state intervention in agriculture including subsidization for production inputs and made structural adjustment reforms. Moreover, wheat production indices decreased during 1986 - 1990, while it increased sharply in the period 1996 - 2000. Again, it fluctuated up to the year 2016 - 2019. Due to time passes, the government gave more emphasis on modern Boro cultivation to attain selfsufficiency in rice production. Consequently, both area and production of wheat decreased in this period. However, the production of Aus rice indices decreased during 2006 - 2010 from its base period and then increased slightly due to intensive government intervention in the cultivation of Aus rice. It is imperative to note that, the level of yield increased for all types of food grains from their base period due to the cultivation of better crop genotypes and also for providing input subsidy by the government. 
Table 1. Index of area, production and yield of cereal crops in Bangladesh

\begin{tabular}{|c|c|c|c|c|c|c|}
\hline Index period & $\begin{array}{l}\text { Aus } \\
\text { rice }\end{array}$ & $\begin{array}{c}\text { Aman } \\
\text { rice }\end{array}$ & $\begin{array}{c}\text { Boro } \\
\text { rice }\end{array}$ & $\begin{array}{l}\text { Total } \\
\text { rice }\end{array}$ & Wheat & Maize \\
\hline \multicolumn{7}{|c|}{ Area ('000' ha) } \\
\hline 1971-1975 & $\begin{array}{c}100 \\
(3128)\end{array}$ & $\begin{array}{c}100 \\
(5611)\end{array}$ & $\begin{array}{c}100 \\
(1080)\end{array}$ & $\begin{array}{c}100 \\
(9819)\end{array}$ & NA & NA \\
\hline $1976-1980$ & 101 & 105 & 99 & 103 & NA & NA \\
\hline 1981-1985 & 97 & 106 & 134 & 106 & $\begin{array}{c}100 \\
(559) \\
\end{array}$ & NA \\
\hline $1986-1990$ & 81 & 101 & 204 & 106 & 105 & NA \\
\hline 1991-1995 & 54 & 102 & 244 & 102 & 113 & $\begin{array}{l}100 \\
(7)\end{array}$ \\
\hline $1996-2000$ & 46 & 101 & 308 & 106 & 143 & 270 \\
\hline $2001-2005$ & 37 & 99 & 365 & 108 & 112 & 782 \\
\hline $2006-2010$ & 32 & 97 & 427 & 113 & 71 & 2336 \\
\hline $2011-2015$ & 34 & 99 & 443 & 116 & 75 & 3989 \\
\hline 2016-2019 & 34 & 99 & 439 & 116 & 65 & 6467 \\
\hline \multicolumn{7}{|c|}{ Production ('000' ton) } \\
\hline $1971-1975$ & $\begin{array}{c}100 \\
(2695)\end{array}$ & $\begin{array}{c}100 \\
(6205)\end{array}$ & $\begin{array}{c}100 \\
(2113)\end{array}$ & $\begin{array}{c}100 \\
(11013)\end{array}$ & NA & NA \\
\hline $1976-1980$ & 115 & 119 & 103 & 115 & NA & NA \\
\hline $1981-1985$ & 113 & 126 & 167 & 130 & $\begin{array}{c}100 \\
(1167)\end{array}$ & NA \\
\hline $1986-1990$ & 102 & 133 & 255 & 149 & 87 & NA \\
\hline 1991-1995 & 71 & 147 & 321 & 162 & 103 & $\begin{array}{l}100 \\
(17)\end{array}$ \\
\hline 1996-2000 & 67 & 154 & 465 & 192 & 149 & 535 \\
\hline $2001-2005$ & 65 & 174 & 612 & 231 & 104 & 1636 \\
\hline $2006-2010$ & 65 & 184 & 825 & 278 & 74 & 5674 \\
\hline $2011-2015$ & 85 & 211 & 895 & 311 & 107 & 11254 \\
\hline 2016-2019 & 96 & 231 & 915 & 329 & 102 & 21318 \\
\hline \multicolumn{7}{|l|}{ Yield (t/ha) } \\
\hline $1971-1975$ & $\begin{array}{c}100 \\
(0.86)\end{array}$ & $\begin{array}{c}100 \\
(1.11)\end{array}$ & $\begin{array}{c}100 \\
(1.96)\end{array}$ & $\begin{array}{c}100 \\
(1.12)\end{array}$ & NA & NA \\
\hline 1976-1980 & 115 & 114 & 103 & 112 & NA & NA \\
\hline 1981-1985 & 116 & 119 & 124 & 123 & $\begin{array}{c}100 \\
(2.08)\end{array}$ & NA \\
\hline 1986-1990 & 126 & 132 & 124 & 141 & 83 & NA \\
\hline 1991-1995 & 131 & 144 & 131 & 158 & 91 & $\begin{array}{c}100 \\
(2.13)\end{array}$ \\
\hline 1996-2000 & 145 & 153 & 149 & 181 & 104 & 218 \\
\hline $2001-2005$ & 178 & 176 & 167 & 214 & 92 & 236 \\
\hline $2006-2010$ & 204 & 189 & 192 & 247 & 105 & 278 \\
\hline 2011-2015 & 249 & 213 & 201 & 268 & 144 & 322 \\
\hline $2016-2019$ & 286 & 234 & 207 & 285 & 156 & 378 \\
\hline
\end{tabular}

Note: Figures in the parentheses indicate the area (' 000 ' ha), production (' 000 ' ton), and yield ( $\mathrm{t} / \mathrm{ha}$ ), respectively for the base period, and 'NA' means data not available.

\section{Growth in area, production, and productivity of cereal food grains}

In the pre-independence period (1947/48 to 1970/71), the overall growth rates of production of cereals were higher than that of area (Table 2). The analysis further showed that the area, production, and yield of all types of food grains registered positive growth rates during the pre-adoption period of modern/high yielding varieties. Moreover, the growth rates for area and production of wheat was higher than that of rice and maize. In the early sixties, the variety IR8 was first introduced in Bangladesh in Boro season. As such, among the rice seasons, the growth rate of both area and production for Boro was higher than that for the other two seasons.

There is a structural break in the time series data for the period after independence. The analysis showed that in sub- period I (1971/72 to 1983/84), overall area, production, and yield of all types of cereals had positive growth rates except for maize. In this period, the growth in the area for Aus, Aman, and Boro slowed down while the growth for production accelerated most likely due to the adoption of the Bangladesh Rice Research Institute (BRRI) developed high yielding rice varieties. At the same time, subsidy on complementary inputs was introduced by the government for enhancing food grain production in the country. Among the food grains, the growth of the area of wheat was higher than that of total rice and maize. However, the growth of the production of rice was higher than that of wheat and maize (Table 2). In this period, the growth of both area and production of maize was negative due to the non-availability of improved genotypes of maize in one hand and on the other hand, public intervention emphasis for proper dissemination and expansion of maize cultivation was less.

In sub-period II (1984/85 to 2018/19), the growth of overall food grain production was found positive because the production growth rate was higher than the growth in the area. The analysis further showed that the growth of area under Aus and wheat had a negative trend in this period (Table 2). With time passes, the area of Aus, Aman, and wheat probably shifted to Boro and maize production. Consequently, growth in both Boro and maize area was positive since the government gave more importance to modern Boro rice production to attain rice self-sufficiency. Similarly, the government also gave importance on maize area expansion to meet up the requirement of poultry and fish feed in the country. Results further show that the maize productivity growth rate was really impressive $(6.90 \%)$, while the productivity growth for total rice and wheat was $2.57 \%$ and $1.53 \%$, respectively.

\section{Structural stability test for cereal food grains production (1947/48 to 2018/19)}

Results of the structural stability test for area, production, and yield of cereal foods for the aforesaid period are presented in Table 3. Analysis reveals that all the differential intercepts $\left(\beta_{2}\right)$ of different food grains area, production, and yield were highly significant and all the first null hypotheses are rejected (except Boro rice area and Aman production, and wheat yield). This implies that there are significant differences in the area, production, and yield of different food grains between the period of pre-establishment of research organizations (1947/48 - 1970/71) and post establishment of research organizations (1971/72 - 2018/19) which is originated from the intercepts. On the other hand, the differential slop coefficient $\left(\beta_{4}\right)$ indicates the nature of changes occurred in the area, production, and yield of different food grains over time.

All the area coefficient of $\beta_{4}$ are significant at $1 \%$ level (except Boro area) and all the $2^{\text {nd }}$ null hypotheses relevant to Aus area, Aman area, total rice area, wheat area, and maize area are rejected which indicate that there are structural changes in the area of different food grains during post establishment of research organizations. Structural stability with respect to production and yield of the aforesaid crops, are also offered in Table 3 . The coefficients of production $\left(\beta_{4}\right)$ of Aus, total rice, wheat, and maize are significant at $1 \%$ level and $2^{\text {nd }}$ null hypotheses are rejected (except Aman and Boro rice production) which indicate that there are structural changes in the production of different food grains during the period of post establishment of research organizations (1971/72 - 2018/19). It also appears in Table 3 that, the coefficients of cereal food grains yield $\left(\beta_{4}\right)$ are significant at $1 \%$ 
level (except for wheat yield). The $2^{\text {nd }}$ null hypothesis is rejected which indicates that there are structural changes in the food grain productivity during the period of post establishment of research organizations.

Table 2. Estimated growth of different cereal crops in Bangladesh over 1947/48 - 2018/19.

\begin{tabular}{|c|c|c|c|c|c|c|}
\hline \multirow[t]{2}{*}{ Periods } & \multicolumn{6}{|c|}{ Growth rates $(\%)^{\mathrm{a}}$} \\
\hline & $\begin{array}{l}\text { Aus } \\
\text { rice }\end{array}$ & $\begin{array}{c}\text { Aman } \\
\text { rice }\end{array}$ & $\begin{array}{c}\text { Boro } \\
\text { rice }\end{array}$ & $\begin{array}{l}\text { Total } \\
\text { rice }\end{array}$ & Wheat & Maize \\
\hline \multicolumn{7}{|c|}{ Area ('000' ha) } \\
\hline $\begin{array}{c}1947 / 48- \\
1970 / 71 \\
\end{array}$ & $2.18^{* * * *}$ & $-0.29^{* * *}$ & $4.91^{* * *}$ & $1.04^{* * *}$ & $5.10^{* * * *}$ & $0.72^{\mathrm{ns}}$ \\
\hline $\begin{array}{c}1971 / 72- \\
2018 / 19\end{array}$ & $-2.38^{* * * *}$ & $-0.12^{* * *}$ & $3.88^{* * * *}$ & $.33^{* * *}$ & $2.20^{\mathrm{ns}}$ & 11.5 \\
\hline $\begin{array}{c}1971 / 72- \\
1983 / 84\end{array}$ & $0.24^{\mathrm{ns}}$ & $0.80^{* * *}$ & $2.98^{* * *}$ & $.83^{* * *}$ & 12 & ? \\
\hline $\begin{array}{c}1984 / 85- \\
2018 / 19 \\
\end{array}$ & $-2.92^{* * *}$ & $-0.14^{*}$ & $3.30^{* * * *}$ & $0.38^{* * * *}$ & $-2.03^{* * *}$ & $16.30^{* * * *}$ \\
\hline \multicolumn{7}{|c|}{ Production ('000' ton) } \\
\hline $\begin{array}{r}1947 \\
197\end{array}$ & $3.35^{* * *}$ & $1.24^{* * * *}$ & $8.11^{* * *}$ & $2.26^{* * *}$ & $7.05^{* * * *}$ & $1.92^{* *}$ \\
\hline $\begin{array}{l}1971 / 72- \\
20018 / 19\end{array}$ & -0 . & & ;* & & & $17.15^{* * *}$ \\
\hline $\begin{array}{c}1971 / 72- \\
1983 / 84 \\
\end{array}$ & $2.40^{* * *}$ & $2.54^{* * *}$ & $4.95^{* * *}$ & $2.99^{* * *}$ & $2.32^{* * *}$ & -3.6 \\
\hline $\begin{array}{c}1984 / 85- \\
2018 / 19\end{array}$ & $-0.03^{\mathrm{ns}}$ & $1.80^{* * * *}$ & $4.96^{* * *}$ & $2.95^{* * *}$ & $-0.52^{\mathrm{ns}}$ & $23.08^{* * * *}$ \\
\hline \multicolumn{7}{|l|}{ Yield (t/ha) } \\
\hline $\begin{array}{c}1947 / 48- \\
1970 / 71\end{array}$ & $1.21^{* * * *}$ & $0.99^{* * * *}$ & $3.39^{* * *}$ & $1.23^{* * *}$ & $1.74^{* * * *}$ & $1.40^{* * * *}$ \\
\hline $\begin{array}{l}1971 / 72- \\
20018 / 19 \\
\end{array}$ & $2.36^{* * *}$ & $1.88^{* * * *}$ & $1.75^{* * *}$ & $2.52^{* * * *}$ & 2.3 & $5.70^{* * * *}$ \\
\hline $\begin{array}{c}1971 / 72- \\
1983 / 84 \\
\end{array}$ & $2.21^{* * * *}$ & $1.80^{* * *}$ & $1.87^{* * *}$ & $2.13^{* * *}$ & $8.74^{* * * *}$ & $-3.42^{* *}$ \\
\hline $\begin{array}{c}1984 / 85- \\
2018 / 19 \\
\end{array}$ & $2.89^{* * * *}$ & $1.94^{* * * *}$ & $1.79^{* * * *}$ & $2.57^{* * * *}$ & $1.53^{* * *}$ & $6.90^{* * * *}$ \\
\hline
\end{tabular}

Note: ' $* * *$ ', ' $* *$ ' and ' $*$ ' indicate significance at $1 \%, 5 \%$ and $10 \% \mathrm{lev}$ els of probability and 'ns' means not significant. 'a' growth rate $(\%)$ estimated through removing autocorrelation using AR1 and heteroscedasticity by MLE. Source: Prepared by authors based on data from Kurosaki, 2011 and BBS, various issues.
Structural stability test for the period 1971/72 to 2018/19

Results on structural stability tests for post-independence periods are furnished in Table 4. It is evident that all the differential intercepts $\left(\beta_{2}\right)$ of different food grains like Aus, Aman, Boro, wheat, and maize area were highly significant at $1 \%$ level of probability. Likewise, the production of Boro rice was significant at 5\% level, wheat and maize were highly significant at $1 \%$ level of probability. Also, Aus yield coefficient was negative and highly significant at $1 \%$ level of probability and the average yield of total rice coefficient was also negative and marginally significant at $10 \%$ level whereas wheat and maize were highly significant at $1 \%$ level of probability implying that there was a structural change occurred in $2^{\text {nd }}$ period over time.

Accordingly, all the $1^{\text {st }}$ null hypotheses are rejected (except for total rice area, Aus production, Aman production, total rice production, Aman yield, and Boro yield) implying that there are differences in the area, production and yield level of different food grains between the two periods (1971/72 1983/84) and (1984/85 - 2018/19) which is originated from the intercept. Nevertheless, the differential slope coefficient $\left(\beta_{4}\right)$ indicates the nature of changes occurred in the area, production, and yield of food grains over time. All the $\beta_{4}$ coefficients are significant at $1 \%$ level (except Boro rice area), while the coefficient of Aman, Boro, and total rice production was insignificant. The analysis also reveals that the $2^{\text {nd }}$ null hypotheses are rejected indicating there are structural changes in the area and production of different food grains during the period of 1984/85 - 2018/19 due to structural adjustment reforms initiated by the World Bank and also due to the continuation of government subsidies on inputs in this period. It is further evidence that the productivity of both wheat and maize is significant at $1 \%$ level and the $2^{\text {nd }}$ null hypotheses are rejected indicating there are structural changes in the productivity of wheat and maize probably due to adoption of improved crop genotypes and also due to the intervention by the World Bank in this period.

Table 3. Test of structural stability in the area, production, and yield between Pre-establishment of research organizations period (1947/48 - 1970/71) and Post-establishment of research organizations period (1971/72 - 2018/19) for food grains.

\begin{tabular}{|c|c|c|c|c|c|c|c|c|c|}
\hline Items & $\beta_{1}$ & $\boldsymbol{\beta}_{2}$ & $\boldsymbol{\beta}_{3}$ & $\boldsymbol{\beta}_{4}$ & $R^{2}$ (F-value) & $\gamma_{1}\left(\beta_{1}+\beta_{2}\right)$ & $\gamma_{2}\left(\boldsymbol{\beta}_{3}+\boldsymbol{\beta}_{4}\right)$ & Ho: $\gamma_{1}=\beta_{1}$ & Ho: $\gamma_{2}=\beta_{3}$ \\
\hline \multicolumn{10}{|c|}{ Area ('000' ha) } \\
\hline Aus rice & $7.553^{\text {***** }}$ & $1.482^{\text {***** }}$ & $0.022^{\text {***** }}$ & $-0.005^{* * * *}$ & $0.91^{* * *}(240.48)$ & 9.035 & 0.016 & Rejected & Rejected \\
\hline Aman rice & $8.618^{* * * *}$ & $0.083^{* * * *}$ & $0.003^{* * *}$ & $-0.004^{* * * *}$ & $0.18^{* * * *}(6.12)$ & 8.701 & -0.001 & Rejected & Rejected \\
\hline Boro rice & $5.510^{* * * * *}$ & $0.365^{* * * *}$ & $0.041^{* * * * *}$ & $-0.001^{\mathrm{ns}}$ & $0.97^{* * *}(847.65)$ & 5.876 & 0.040 & Rejected & Accepted \\
\hline Total rice & $8.938^{* * * *}$ & $0.171^{\text {**** }}$ & $0.010^{* * * *}$ & $-0.007^{* * * *}$ & $0.91^{* * *}(239.34)$ & 9.110 & 0.003 & Rejected & Rejected \\
\hline Wheat & $3.380^{* * * * *}$ & $1.935^{* * * *}$ & $0.049^{* * * *}$ & $-0.033^{* * * *}$ & $0.85^{* * * *}(1137.48)$ & 5.315 & 0.016 & Rejected & Rejected \\
\hline Maize & $1.286^{* * * *}$ & $-4.89^{* * * *}$ & $0.005^{\text {**** }}$ & $0.127^{* * *}$ & $0.91^{* * * *}(227.06)$ & -3.603 & 0.132 & Rejected & Rejected \\
\hline \multicolumn{10}{|c|}{ Production ('000' ton) } \\
\hline Aus rice & $7.235^{* * * *}$ & $0.973^{* * * *}$ & $0.033^{* * * *}$ & $-0.043^{* * * *}$ & $0.48^{* * * *}(22.96)$ & 8.208 & -0.010 & Rejected & Rejected \\
\hline Aman rice & $8.521^{* * * *}$ & $-0.23^{\text {***** }}$ & $0.128^{* * * *}$ & $0.005^{\mathrm{ns}}$ & $0.92^{\text {***** }}(267.10)$ & 8.292 & 0.133 & Rejected & Accepted \\
\hline Boro rice & $5.280^{* * * *}$ & $0.766^{* * *}$ & $0.753^{* * *}$ & $-0.173^{\mathrm{ns}}$ & $0.98^{* * *}(995.95)$ & 6.046 & 0.580 & Rejected & Rejected \\
\hline Total rice & $8.776^{* * * *}$ & $-0.26^{* * * *}$ & $0.023^{\text {***** }}$ & $0.006^{* * *}$ & $0.98^{* * * *}(133.9)$ & 8.520 & 0.028 & Rejected & Rejected \\
\hline Wheat & $2.681^{* * * *}$ & $2.429^{\text {**** }}$ & $0.066^{\text {**** }}$ & $-0.032^{* *}$ & $0.90^{* * * *}(222.71)$ & 5.111 & 0.034 & Rejected & Rejected \\
\hline Maize & $0.795^{* * * *}$ & $-6.80^{* * *}$ & $0.195^{\mathrm{ns}}$ & $0.179^{* * * *}$ & $0.93^{* * * *}(301.34)$ & -6.008 & 0.374 & Rejected & Rejected \\
\hline \multicolumn{10}{|c|}{ Yield (t/ha) } \\
\hline Aus rice & $-0.323^{\text {***** }}$ & $-0.51^{* * * * *}$ & $0.012^{* * * *}$ & $0.010^{* * * * *}$ & $0.93^{* * * *}(306.10)$ & -0.830 & 0.023 & Rejected & Rejected \\
\hline Aman rice & $-0.100^{\text {**** }}$ & $-0.31^{\text {**** }}$ & $0.010^{\text {***** }}$ & $0.008^{* * * *}$ & $0.95^{* * * *}(491.74)$ & -0.406 & 0.019 & Rejected & Rejected \\
\hline Boro rice & $-0.228^{* * * *}$ & $0.397^{* * * *}$ & $0.340^{\text {**** }}$ & $-0.016^{* * * *}$ & $0.96^{* * * *}(552.03)$ & 0.168 & 0.324 & Rejected & Rejected \\
\hline Ave. rice & $-0.163^{\text {**** }}$ & $-0.43^{* * * *}$ & $0.012^{* * * *}$ & $0.013^{* * *}$ & $0.98^{* * * *}(1544.16)$ & -0.593 & 0.025 & Rejected & Rejected \\
\hline Wheat & $-0.702^{* \cdots * *}$ & $0.49^{* * * *}$ & $0.174^{* * * *}$ & $0.001^{\mathrm{ns}}$ & $0.91^{* * * *}(246.19)$ & -0.217 & 0.175 & Rejected & Accepted \\
\hline Maize & $-0.488^{\text {**** }}$ & $-1.92^{* * *}$ & $0.014^{\mathrm{ns}}$ & $0.052^{* * *}$ & $0.89^{* * * *}(197.82)$ & -2.407 & 0.066 & Rejected & Rejected \\
\hline
\end{tabular}

Note: '***', ‘**', and '*' indicate significance at $1 \%, 5 \%$ and $10 \%$ levels of probability and 'ns' means not significant. 
Table 4. Test of structural stability in the area, production, and yield between (1971/72 - 1983/84) and (1984/85 2018/19) for food grains in Bangladesh.

\begin{tabular}{|c|c|c|c|c|c|c|c|c|c|}
\hline Items & $\beta_{1}$ & $\boldsymbol{\beta}_{2}$ & $\beta_{3}$ & $\boldsymbol{\beta}_{4}$ & $\begin{array}{c}\mathbf{R}^{2} \\
\text { (F-value) } \\
\end{array}$ & $\begin{array}{c}\gamma_{1} \\
\left(\beta_{1}+\beta_{2}\right)\end{array}$ & $\begin{array}{c}\gamma_{2} \\
\left(\beta_{3}+\beta_{4}\right)\end{array}$ & $\begin{array}{c}\text { Ho: } \\
\gamma_{1}=\beta_{1}\end{array}$ & $\begin{array}{c}\text { Ho: } \\
\gamma_{2}=\beta_{3}\end{array}$ \\
\hline \multicolumn{10}{|c|}{ Area ('000' ha) } \\
\hline Aus rice & $8.037^{* * * * *}$ & $0.237^{* * *}$ & $0.002^{\mathrm{ns}}$ & $-0.035^{* * * *}$ & $0.92^{* * * *}(172.72)$ & 8.274 & -0.033 & Rejected & Rejected \\
\hline Aman rice & $8.611^{* * * *}$ & $0.062^{* *}$ & $0.008^{* * * *}$ & $-0.009^{* * * *}$ & $0.32^{* * * *}(8.47)$ & 8.673 & -0.001 & Rejected & Rejected \\
\hline Boro rice & $6.833^{* * *}$ & $0.274^{* * *}$ & $0.028^{* * * *}$ & $0.005^{\mathrm{ns}}$ & $0.96^{* * *}(362.77)$ & 7.107 & 0.033 & Rejected & Accepted \\
\hline Total rice & $9.160^{* * * *}$ & $-0.007^{\mathrm{ns}}$ & $0.008^{* * * *}$ & $-0.004^{* *}$ & $0.75^{* * *}(48.10)$ & 9.154 & 0.004 & Accepted & Rejected \\
\hline Wheat & $4.379^{* * * *}$ & $2.482^{* * * *}$ & $0.159^{* * * *}$ & $-0.178^{* * * *}$ & $0.85^{* * * *}(87.70)$ & 6.862 & -0.018 & Rejected & Rejected \\
\hline Maize & $0.972^{* * *}$ & $-2.827^{* * * *}$ & $-0.012^{\mathrm{ns}}$ & $0.186^{* * *}$ & $0.98^{* * * *}(702.50)$ & -1.855 & 0.174 & Rejected & Rejected \\
\hline \multicolumn{10}{|c|}{ Production ('000' ton) } \\
\hline$A u s$ rice & $7.823^{* * * *}$ & $-0.053^{\mathrm{ns}}$ & $0.024^{*}$ & $-0.028^{* *}$ & $0.42^{* * * *}(12.48)$ & 7.770 & -0.004 & Accepted & Rejected \\
\hline Aman rice & $8.665^{* * *}$ & $0.024^{\mathrm{ns}}$ & $0.025^{* * * *}$ & $-0.008^{\mathrm{ns}}$ & $.91^{* * * *}(152.68)$ & 8.689 & 0.018 & Accepted & Accepted \\
\hline Boro rice & $7.430^{* * * *}$ & $0.237^{\text {*** }}$ & $0.048^{* * * *}$ & $0.004^{\mathrm{ns}}$ & $0.97^{* * * *}(559.21)$ & 7.666 & 0.052 & Rejected & Accepted \\
\hline Total rice & $9.206^{* * * *}$ & $-0.062^{\mathrm{ns}}$ & $0.302^{* * * *}$ & $0.000^{\mathrm{ns}}$ & $0.98^{* * * *}(796.47)$ & 9.143 & 0.301 & Accepted & Accepted \\
\hline Wheat & $4.114^{* * *}$ & $3.013^{* * *}$ & $0.250^{\text {**** }}$ & $-0.253^{* * *}$ & $0.89^{* * *}(133.34)$ & 7.127 & -0.002 & Rejected & Rejected \\
\hline Maize & $0.903^{* * *}$ & $-3.775^{* * * *}$ & $-0.051^{\mathrm{ns}}$ & $0.297^{* * *}$ & $0.97^{* * * *}(602.34)$ & -2.872 & 0.246 & Rejected & Rejected \\
\hline \multicolumn{10}{|l|}{ Yield (t/ha) } \\
\hline Aus rice & $-0.217^{* * * *}$ & $-0.286^{* * * *}$ & $0.022^{* * * *}$ & $0.007^{\mathrm{ns}}$ & $.96^{* * * *}(385.72)$ & -0.503 & 0.029 & Rejected & Accepted \\
\hline Aman rice & $0.053^{\mathrm{ns}}$ & $-0.032^{\mathrm{ns}}$ & $0.018^{* * * *}$ & $0.001^{\mathrm{ns}}$ & $0.95^{* * *}(317.53)$ & 0.020 & 0.019 & Accepted & Accepted \\
\hline Boro rice & $0.597^{* * * *}$ & $-0.043^{\mathrm{ns}}$ & $0.020^{* * * *}$ & $-0.001^{\mathrm{ns}}$ & $0.96^{* * * *}(354.84)$ & 0.554 & 0.019 & Accepted & Accepted \\
\hline Ave. rice & $0.047^{*}$ & $-0.058^{*}$ & $0.021^{\text {***** }}$ & $0.005^{\mathrm{ns}}$ & $0.99^{* * * * *}(1128.44)$ & -0.011 & 0.026 & Rejected & Accepted \\
\hline Wheat & $-0.270^{* * * *}$ & $0.536^{* * *}$ & $0.092^{* * * *}$ & $-0.075^{* * * *}$ & $0.80^{* * * *}(64.26)$ & 0.265 & 0.017 & Rejected & Rejected \\
\hline Maize & $-0.068^{\mathrm{ns}}$ & $-0.952^{* * * *}$ & $-0.039^{*}$ & $0.112^{* * *}$ & $0.90^{* * * *}(146.34)$ & -1.020 & 0.073 & Rejected & Rejected \\
\hline
\end{tabular}

Note: '***', '**', and '*' indicate significance at $1 \%, 5 \%$ and $10 \%$ levels of probability and 'ns' means not significant.

\section{Supply response behavior of food grains}

An attempt was made to study the supply response scenario of food grains e.g., Aus, Boro, and wheat in Bangladesh during the period $1971 / 72$ to $2017 / 18$. The relevant competing crops selected with respect to the above crops were jute, wheat, and Boro. Supply response functions fitted for various food crops showed that Aus rice competed with jute while Boro and wheat were the competing crops to each other.

It was assumed that the area under food grains is likely to be influenced by different variables such as lagged area, lagged relative price, lagged relative yield, relative price risk, relative yield risk, and gross irrigated area. Price is considered to be one of the important factors that influence farmers' allocation of areas for crop production. Usually, farmers produce different crops mostly depending on the previous year's harvest price of the crop. As such, the harvest prices of crops were taken into consideration in the analysis, because wholesale and retail prices may not sometime reflect the actual price received by the farmers. On the other hand, the risks due to variations in yield and price are expected to act as deterrent factors on acreage under various food corps during a particular year. Therefore, only the price and yield risk or the coefficient of variations $(\mathrm{CV})$ of prices and yield of different food crops for the preceding one year were used in the analysis as risk variables. This might be an appropriate way to incorporate risk particularly in the annual time series aggregate model (Sidhu and Sidhu, 1988). This study employed the Cochrane-Orcutt procedure (Gujarati, 2003) for removing the autocorrelation problems in the models. The study also hypothesized that an increase in the gross irrigated area would cause a reduction in the area under similar competing crops or food crops. This is because old varieties of most of these crops give lower yields on irrigated land, whereas modern varieties of Aus, Boro, and wheat give a very high yield in a similar ecosystem or land type. However, the estimated elasticity coefficients of different supply response variables are depicted in Table 5.

\section{Lagged area}

The elasticity estimates of lagged areas for Aus, Boro, and wheat were found to be positive and significant at $1 \%$ level implying that allocation of the area under Aus, Boro, and wheat in the preceding year had a significant influence on land allocation for the following year. The lagged area influence was found higher on the allocation of land for Aus production followed by wheat and Boro, respectively. The magnitude of the partial elasticity coefficient for Aus, wheat, and Boro were $0.963,893$, and 0.789 , respectively, indicating that the farmers had considerably high adjustment responses towards these factors (Table 5).

\section{Lagged relative price}

The results of the regression analysis (in Table 5) show that the relative price of Aus and Boro vis-a-vis jute and wheat had a negative and insignificant impact on the area under Aus and Boro in Bangladesh. The insignificant impact of the relative price variable would show that the farmers did not take into consideration the changes in relative prices of Aus and Boro while allocating areas for these crops for the following year. On the other hand, the coefficient of relative price was positive in the case of wheat. However, the coefficient was not significant.

\section{Lagged relative yield}

The lagged relative yield of wheat concerning competing for crop Boro registered positive and significant impact on area devotion to wheat production. The short-run partial elasticity of wheat with respect to the relative yield variable was 0.401 at the macro level (Table 5). The lagged relative yield of Boro turned out to be positive implying that Boro season farmers took into consideration the lagged relative yield of Boro vis-a-vis wheat during the allocation of land for Boro and wheat cultivation. On the other hand, the coefficient of relative yield was positive in the case of Aus. However, the coefficient was not significant. 


\section{Risk factors}

In the analysis both relative price and yield risk factors were taken into considered assuming that, risk arose probably due to variations in relative price and relative yield. The coefficient of the pertinent partial elasticity of Boro was negative while for Aus it was positive and insignificant (Table 5). On the other hand, it was positively significant for wheat. Price risk variables with negative signs implied farmers' risk aversion response to price fluctuation. On the other hand, farmers considered relative price risk significantly during the allocation of area for wheat cultivation.

The elasticities of yield risk variables were found to be positive and insignificant for Aus indicating that, the farmers did not consider relative yield risk in devoting area for cultivating the aforesaid crop. On the other hand, the yield risk variable was found negative and insignificant in the case of Boro and wheat implying that yield risk factor had a negative influence on the allocation of land for these two crops.

\section{Irrigated Area}

The coefficient of irrigated area in Aus and wheat had a negative sign implying that irrigation had the most adverse impact on the cultivation of Aus rice and wheat. The partial elasticity coefficient of irrigation for $A u s$ and wheat were negative and insignificant (Table 5). However, the same variable for Boro was positively significant at $1 \%$ level of probability, with respect to area devotion for Boro. This implies that a one percent increase in the gross irrigated area would increase the Boro area by $0.107 \%$. In fact, farmers usually take into consideration the availability of irrigation during the allocation of land for Boro cultivation. An earlier study also postulated a similar result (Jabber and Alam 1999).

Table 5. Results of area devotion to supply response functions for cereals (Boro, Aus, and wheat) in Bangladesh, $1971 / 72$ to $2017 / 18$

\begin{tabular}{|c|c|c|c|}
\hline Variables & Boro & Aus & Wheat \\
\hline Constant & $1.389^{\text {***** }}$ & $0.896^{\mathrm{ns}}$ & $1.916^{* * * *}$ \\
\hline Ln lagged area $\left(\mathrm{A}_{\mathrm{t}-1}\right)$ & $0.789^{* * * *}$ & $0.963^{* * *}$ & $0.898^{* * *}$ \\
\hline $\begin{array}{l}\text { Ln lagged relative } \\
\text { price }\left(\mathrm{RP}_{\mathrm{t}-1}\right)\end{array}$ & $-0.010^{\mathrm{ns}}$ & $-0.022^{\mathrm{ns}}$ & $0.003^{\mathrm{ns}}$ \\
\hline $\begin{array}{l}\text { Ln lagged relative } \\
\text { yield }\left(\mathrm{RY}_{\mathrm{t}-1}\right)\end{array}$ & $0.129^{* * *}$ & $0.071^{\mathrm{ns}}$ & $0.401^{* *}$ \\
\hline $\begin{array}{l}\text { Ln relative price risk } \\
\left(\mathrm{CV}_{\mathrm{RP}}\right)\end{array}$ & $-0.011^{\mathrm{ns}}$ & $0.001^{\mathrm{ns}}$ & $0.026^{*}$ \\
\hline $\begin{array}{l}\text { Ln relative yield risk } \\
\left(\mathrm{CV}_{\mathrm{RY}}\right)\end{array}$ & $-0.012^{\mathrm{ns}}$ & $0.014^{\mathrm{ns}}$ & $-0.001^{\mathrm{ns}}$ \\
\hline $\begin{array}{l}\text { Ln gross irrigated area } \\
\left(\mathrm{I}_{\mathrm{t}}\right)\end{array}$ & $0.107^{* *}$ & $-0.026^{\mathrm{ns}}$ & $-0.031^{\mathrm{ns}}$ \\
\hline \multicolumn{4}{|l|}{ Diagnostic statistic: } \\
\hline Adjusted $\mathrm{R}^{2}$ & 0.9828 & 0.9855 & 0.9698 \\
\hline F value & $431.60^{\text {****** }}$ & $509.96^{* * * *}$ & $241.64^{* * * * *}$ \\
\hline $\begin{array}{l}\text { D-W test statistics } \\
\text { (original) }\end{array}$ & 2.06 & 2.26 & 2.12 \\
\hline $\begin{array}{l}\text { D-W test statistics } \\
\text { (transformed) }\end{array}$ & 2.01 & 1.99 & 1.90 \\
\hline Sample size & 47 & 47 & 47 \\
\hline
\end{tabular}

Note: ' $* * *$ ' ‘ $* *$ ' ‘ $*$ ' represents, significant at $1 \%, 5 \%$, and $10 \%$ level of probability and 'ns' means not significant.

\section{Conclusions}

This study has designed to show the supply response scenario of food grains in Bangladesh using time series data. For this, the study considered two breakdown periods of intervention; period 1 (1971-1983) was considered for substantial technological advancement in agriculture, and establishment of research organizations, whereas period 2 (1984 - 2019) was for structural adjustment reforms initiated by the World Bank and development of improved genotypes.

The empirical findings revealed that the allocation of the area under Aus rice, Boro rice, and wheat in the preceding year had a significant influence on land allocation for the current year. The magnitude of the partial elasticity for Aus rice, wheat and Boro rice were 0.963, 893, and 0.789, respectively, indicating that the farmers had considerably high adjustment response towards these factors. The findings also showed that the change in relative price did not have influence on allocating areas for Aus and Boro rice. The lagged relative yield of wheat with respect to competing Boro rice has registered a positive and significant impact on area devotion to wheat. The Boro farmers took into consideration of the lagged relative yield of Boro rice vis-a-vis wheat in allocating land for Boro rice and wheat cultivation. However, farmers considered relative price risk significantly in allocating land for wheat cultivation. The yield risk variable was found negative in the case of Boro rice and wheat implying that yield risk factor had no influence on the cultivation of these two crops. Irrigation availability had a positive impact on area devotion to Boro rice production. Farmers in Bangladesh usually take into consideration the availability of irrigation in allocating land for Boro rice cultivation, which signifies the essence of extending public efforts in improving irrigation facilities for boosting food grain production in the country.

\section{Policy implications}

The growth rate of cereal production has been showing a deceleration in recent years even though the growth of both area and yield of modern varieties has been increasing. Since the adoption of modern rice technologies has reached a plateau, further advancement in the growth and supply of cereals would require the adoption of newly evolved stress-tolerant varieties in the unexploited large stress-prone areas of the country. There is about 2.85 million hectares of lands covering almost $30 \%$ of the cultivable land falling under the coastal zone, where nearly 0.85 million hectares in 13 southwestern districts are affected by varying degrees of salinity (Rahman et al. 2013; Siddique et al. 2017). Whereas, Drought prone areas cover about 4.0 million ha and nearly $30 \%$ of the Aman area is affected by drought in Bangladesh (BARC 2002). Dissemination and adoption of stress tolerant varieties in these areas would help to enhance the level of rice production substantially. Moreover, it is essential to ensure fair price of the food grains in the farm-gate to sustain the production and keep the growth rate up. The government should strengthen the pricing and market monitoring strategy to provide a profitable value to the food grain farmers.

\section{References}

Abdullah AA (1976). Land Reform and Agrarian Change in Bangladesh, The Bangladesh Development Studies: 4(1).

Alam MS, Quayum MA, Islam MA (2011). The changing crop production practices over the years: The Mystery of Economics, The Bangladesh Journal of Agricultural Research 36(4): 657-668.

BARC (2002). "Report on application of agro-ecological zones database in drought management and water availability assessment", Soil Science Division, Bangladesh Agricultural Research Council, Farmgate, Dhaka, Bangladesh. 
BBS (2016). Statistical yearbook of Bangladesh. Statistics and informatics division, Bangladesh Bureau of Statistics, Ministry of Planning, Government of the Peoples' Republic of Bangladesh, Dhaka.

BBS (2019). Statistical yearbook of Bangladesh. Statistics and informatics division, Bangladesh Bureau of Statistics, Ministry of Planning, Government of the Peoples' Republic of Bangladesh, Dhaka.

Begum MAA, Islam SF, Kamruzzaman M, Kabir MJ, Shiblee SMA (2002). Supply response of wheat in Bangladesh: an application of partial adjustment model, Pakistan Journal of Biological Sciences 5(2): 225-229.

Bose SR (1974). The Cumilla cooperative approach and the prospects of a broad-based green revolution in Bangladesh, World Development 2 (8): 21-28.

Boyce JK (1987) “Agrarian Impasse in Bengal: Institutional Constraints to technological Change?”, Oxford University Press, Oxford.

Brolley M (2015). Rice security is food security for much of the world, Rice Today. International Rice Research Institute (IRRI), DAPO Box, 7777, 30-32.

FPMU (2020). Data Base on Food Situation, Food Planning and Monitoring Unit, Ministry of Food, Government of the Peoples Republic of Bangladesh, Dhaka.

Gujarati DN (2003). "Basic Econometrics" 4th edition McGraw Hill United states Military Academy. West Point.

Hasan MM (2012). "Agricultural Policy Reforms and Structural Adjustments in Bangladesh", MPRA Paper No. 46540, Retrieved on 24 April 2020 from https://mpra.ub.uni-muenchen.de/46540/.

HIES (2019). "Household Income and Expenditure Survey 2016", Bangladesh Bureau of Statistics, Statistics and informatics Division, Published 2019, Ministry of Planning, Government of the Peoples Republic of Bangladesh, Dhaka.

Hossain M (1984). Agricultural Development in Bangladesh: A Historical Perspective, The Bangladesh Development Studies 12(4): 29-57.

Hossain M (2003). "Development of Boro rice cultivation in Bangladesh: trends and policies”. In: Singh, RK, Hossain M, Thakur R (eds). Boro Rice. Pages 25-42, Fine Grains (India) Private Limited, New Delhi, India.

Jabber MA, Alam MS (1999). Two Decades Experience of Rice Productivity in Bangladesh: Implications for Increased Production, Bangladesh Journal of Rural Development Vol. 29(I): 1-13.

Jannuzi FT, Peach JT (1980). “Agrarian Structure in Bangladesh: An Impediment to Development?": West View Press.
Kamal GH (2007). Supply response of boro rice in Bangladesh: cointegraton and error correction modelling approach, Bangladesh Journal of Agricultural Economics 30(2): 19-34.

Kumar AG, Prasad SK, Pullabhotla H (2012). Supply and demand for cereals in Bangladesh, 2010-2030: IFPRIDiscussion Papers, (1186). Retrieved on 20 April 2020 from https://www.ifpri.org/publication/supply-anddemand-cereals-bangladesh-20102030.

Kurosaki T (2011). Compilation of Agricultural Production Data in Areas Currently in India, Pakistan, and Bangladesh from 1901/02 to 2001/02, A revised and extended version of "Compilation of Agricultural Production and Areas Data for India and Pakistan, 1900-1990," COE Discussion Paper No. D 99-24, February 2000, Hitotsubashi University, Japan. www.ier.hitu.ac.jp/primced/e-index.html.

Miah MAM, Quddus MA, Matin MA, Hasan MN, Aktar M (2009). Analysis of Growth and Supply Responses of Selected Pulses in Bangladesh, The Agriculturists Vol. 7, (1\&2): 62-71.

Nerlove M (1956). Estimates of the Elasticities of Supply of Selected Agricultural Commodities, Journal of Farm Economics 38(2): 496-503.

Rahman MC, Siddique AB, Salam MA, Islam MA, Al-faisal MS (2013). Assessment of Technical Efficiency of Rice Farmers in a Selected Empoldered Area of Bangladesh, European Journal of Agricultural Sciences 10:102-110.

Rahman SH (1986). Supply response in Bangladesh agriculture, The Bangladesh development studies: 57-100.

Siddique MAB, Sarkar MAR, Rahman MC, Chowdhury A, Rahaman MS, and Deb L (2017). Rice farmers' technical efficiency under abiotic stresses in Bangladesh, Asian Journal of Agriculture and Rural Development: 7(11), 219-232.

Sidhu JR, Sidhu RS (1988). Growth and Area Response of Commercial Crops in Punjab: Some Policy Issues, Indian Journal of Agricultural Economics: 43(3): 473-480.

United Nations (UN) 2019. "World Population Prospects, the 2019 Revision", United Nations Department of Economic and Social Affairs. Retrieved on 18 April 2020 from https://population.un.org/wpp/Download/Standard/Popul ation/.

WB (1994). "Bangladesh: From Stabilization to Growth", Washington DC: World Bank. Retrieved on 24 April 2020 from http://documents.worldbank.org/ curated/en/987511468742518524/Bangladesh-Fromstabilization-to-growth.

Yaseen MR, Dronne Y, Ahmad I (2011). Estimates supply response of major crops in Bangladesh, The Bangladesh Development Studies: 55-64. 